\title{
https://doi.org/10.52240/1857-2367.2020.2(21).48 \\ MULTIPLICAREA VEGETATIVĂ PRIN BUTAȘI A TAXONILOR DE HYDRANGEA L.
}

\author{
Natalia ONICA \\ Grădina Botanică Națională (Institut) „Al. Ciubotaru”, \\ Chișinău, Republica Moldova
}

\begin{abstract}
The purpose of this study was to develop propagation technology in the pedo-climatic conditions of the Republic of Moldova, to cultivars of the genus Hydrangea L., by vegetative propagation with green cuttings, experimenting with several rhizogenesis substrates and various rooting stimulants in different concentrations.
\end{abstract}

Key words: Hydrangea L., vegetative propagation, cultivars, cuttings, plant rooting hormones, IBA.

Genul Hydrangea L., (familia Hydrangeaceae Dumort.) este reprezentat de arbuști, uneori liane, rareori arbori, cu frunze simple, dinţate, lobate, peţiolate, dispuse altern. Florile sunt dispuse în corimbe terminale sau panicule, cele din mijlocul inflorescenței sunt bisexuate, cele marginale sunt sterile, cu sepale petaloide, stamine 10 (8-20), ovar 2-5-locular, cu numeroase ovule, stile 2-5, libere sau unite la bază; la formele de cultură toate florile sunt sterile. Fructul - capsulă dehiscentă, cu numeroase seminţe mici, aripate. Genul include specii răspândite în Asia de Est şi Sud până la insula Iava şi munţii Himalaya, inclusiv în America de Nord şi Sud. Denumirea genului presupune că speciile acestui gen sunt iubitoare de umiditate [4].

Scopul aceastui studiu a constat în elaborarea tehnologiei de înmulțire în condițiile pedo-climatice ale Republicii Moldova a cultivarurilor din genul Hydrangea L. prin multiplicarea vegetativă cu butași semilignificați, experimentând mai multe substraturi de rizogeneză și diverși stimulatori de înrădăcinare în concentrații diferite. Montarea experiențelor au fost efectuate conform planului de lucru al tezei de doctorat "Genul Hydrangea L. în Republica Moldova (introducţia, particularităţi bioecologice, utilizarea în amenajări peisagistice)".

În studiu au fost luate 60 de cultivaruri ale speciilor existente în colecția de fond a Grădinii Botanice Naționale (Institut) "Alexandru Ciubotaru" și anume de la taxonii: Hydrangea paniculata Siebold, Hydrangea arborescens L., Hydrangea aspera D. Don, Hydrangea quercifolia W. Bartram, Hydrangea macrophylla subsp. serrata (Thunb.) Makino., Hydrangea anomala D. Don care au fost multiplicați prin prelevarea butaşilor în perioada iunie-septembrie (butași semilignificați). Butașii nelignificați, de 10-15 cm lungime, au fost colectați în perioada de vegetatie activă a materialului vegetal, supuși tratării cu 6 variante de concentrații și stimulatori de rizogeneză, precum și varianta Martor: 1) NAA, 0,005\%, Naphthaleneacetic acid; 2) IAA 0,05\%, Indole-3-acetic acid; 3) IBA $0.01 \%$, Indole-3-butyric acid; 4) IAA 0,002\%, Indole-3-acetic acid; 5) VERBASCOZIDĂ $0,01 \%$, (stimulator de rizogeneză realizat de către Institutul de Genetică, Fiziologie şi Protecţie a Plantelor); 6) MOLDSTIM 0,01\%, (stimulator de rizogeneză realizat de către Institutul de Genetică, Fiziologie şi Protecţie a Plantelor).

Butașii colectați și tratați au fost încorporați în mai multe substraturi de rizogeneza: Perlit-100\%; Turbă+Perlit (1:1); Turbă de Sphagnum-100\%, pH 5,5-6,5; Turbă - 100\%, 
pH-3.5-4.5. Plantarea butaşilor s-a efectuat în ziua colectării. Prepararea butaşilor a fost efectuată în spaţiu adăpostit, ferit de soare şi curenţi de aer, pentru a evita deshidratarea acestora. Experienţa a constituit din două repetiţii pentru fiecare variantă câte 10 butaşi. Construcţia plăcilor alveolate asigură drenajul şi aeraţia, astfel încât se omite creşterea spiralată a sistemului radicular. Ulterior, plăcile cu butaşii plantaţi au fost amplasate pe un suport din plastic, pentru favorizarea nu numai a aeraţiei butaşilor, dar şi eliminarea excesului de umiditate din substrat, evitându-se astfel putrezirea lor [1-3, 5]. Primele rădăcini la butașii semilignificați au apărut după 3-4 săptămâni, în dependență de stimulatorul de înrădăcinare și substratul de rizogeneză, iar încă peste 3 săptămâni, cei înrădăcinați au fost transplantați în containere de plastic cu mărimea de 9x9x10 cm, 0,5 dm³.

Ținând cont de o vară cu temperaturi exagerat de ridicate, procentul de înrădăcinare a butașilor nelignificați și netratați cu stimulatori de înrădăcinare a fost de cca $40 \%$, iar la cei tratați cu stimulatori - de la 60 - la 90\%. Prin urmare, recomandăm efectuarea multiplicării vegetative cu butași semilignificați prin tratarea cu stimulatori de rizogeneză.

Cercetările s-au efectuat și continuă în cadrul proiectului: 20.80009.7007.19 „Introducerea și elaborarea tehnologiilor de multiplicare și cultivare prin tehnici convenționale și culturi in vitro a speciilor de plante lemnoase noi".

\section{BIBLIOGRAFIE SELECTIVA}

1. Dirr M., Heuser Ch. Jr. The reference manual of woody plant propagation: From seed to tissue culture. Athens, Georgia, Varsity press, Inc. 1987, 239 p.

2. Dirr M. Manual of Woody Landscape Plants. Identification, Ornamental Characteristic, Propagation and Uses. Fifth edition. Champaign, Illinois, 1998, 1187 p.

3. Dirr M. Dirr's Hardy trees and shrubs. Illustrated encyclopedia. Portland-Cambridge, Timber press. 2005, $493 \mathrm{p}$.

4. Palancean A., Comanici I. Dendrologie. Chişinău: F.E.-P: „Tipogr. Centrală”, 2009, 519 p.

5. Иванова 3. Я. Биологические основы и приемы вегетативного размножения древесных растений стеблевыми черенками. Киев: Наукова думка, 1982, 288 с. 